\title{
СОВРЕМЕННЫЕ ТРЕБОВАНИЯ К ОРГАНИЗАЦИИ СОВМЕСТНОЙ ОБРАЗОВАТЕЛЬНОЙ ДЕЯТЕЛЬНОСТИ В УСЛОВИЯХ ДОШКОЛЬНОГО ОБРАЗОВАНИЯ: НЕОБХОДИМОСТЬ И РЕАЛЬНОСТЬ
}

\section{T. A. Токарева}

Томский государственный педагогический университет, Томск

Описана проблема готовности педагогов дошкольных образовательных организаций к работе по новому федеральному государственному образовательному стандарту дошкольного образования, который уделяет большое внимание организации совместной образовательной деятельности педагога с детьми. Приведены результаты двух анкетных опросов воспитателей детских садов, в процессе которых выяснилось следующее: во-первых, уровень вовлеченности педагогов в разработку образовательных программ; во-вторых, понимание ими результатов дошкольного образования; в-третьих, определение приоритетных направлений развития ребенка-дошкольника. Обнаружено, что большинство педагогов занимают исполнительскую позицию в отношении образовательных программ, акцентированы не на личностном развитии ребенка, а на формировании у него знаний, умений и навыков, недооценивают ценность игры и исследовательской деятельности для детского развития. Описаны реальные образовательные ситуации организации совместной деятельности педагога с детьми, иллюстрирующие, что педагоги не всегда понимают, как сделать ребенка активным участником взаимодействия со взрослым и как уйти от тотального использования авторитарной модели совместной деятельности в сторону лидерства и партнерства. Делается вывод о том, что существует взаимосвязь между уровнем методического сопровождения в дошкольном образовательном учреждении, в том числе позицией старшего воспитателя, и умением педагога организовывать образовательные ситуации обращенного и открытого совместного действия с детьми.

Ключевые слова: образовательная программа, совместная образовательная деятельность, открытое совместное действие, образовательная ситуация, дошкольное образование.

Главным в развитии дошкольного образования (ДО) многие десятилетия было обеспечение бесплатными местами в образовательных учреждениях детей всех семей, пожелавших посещать дошкольные образовательные учреждения (ДОУ). Как правило, желание родителей исходило из необходимости работать, в то время как ребенок будет находиться в детском саду или яслях и получать квалифицированную педагогическую помощь и поддержку. На всем протяжении советского периода основной задачей ДО была организация присмотра и ухода за детьми. В более поздние годы важным считалось формирование общей культуры, подготовка ребенка к обучению в школе, развитие нравственных, эстетических, физических и личностных качеств. Долгие годы ДО оставалось вспомогательным звеном в образовательной системе.

Кардинально изменил понимание системы ДО Федеральный закон от 29 декабря 2012 г. № 273-Ф3 «Об образовании в Российской Федерации» [1]. В этом документе (ст. 10) установлены уровни общего образования, где дошкольное определено как первый уровень общего образования. Это повлекло за собой ряд изменений в нормативно-правовой основе 
регулировании деятельности ДО. Во-первых, впервые в России был разработан и введен Федеральный государственный стандарт дошкольного образования (ФГОС ДО) [2]; во-вторых, услуги по присмотру и уходу за детьми отделены от самого образования, предполагающего реализацию основной образовательной программы в соответствии с ФГОС ДО (№ 273-Ф3 «Об образовании в Российской Федерации» ст. 2, п. 34); в-третьих, приказом Министерства труда и социальной защиты РФ от 18 октября 2013 г. утвержден Профессиональный стандарт, который вступил в законную силу на территории Томской области с 01 января 2017 г. [2].

Дошкольное образование, хотя и стало законной ступенью общего образования, осталось особенным, даже уникальным этапом образования, которое обеспечивает успешность ребенка не только в начальной школе, но и на многие годы вперед. Разностороннее развитие детей дошкольного возраста с учетом их возрастных и индивидуальных особенностей, в том числе достижение детьми уровня развития, необходимого и достаточного для успешного освоения ступени начального общего образования, обеспечивается образовательными программами дошкольного образования. В отличие от иных ступеней образования, освоение дошкольной программы не предусматривает какой-либо аттестации. Педагог в работе с детьми учитывает эффективность усвоения программы - это соотношение цели и результата, что в ФГОС ДО обозначено как целевые ориентиры. Целевые ориентиры ФГОС ДО, с одной стороны, - это планируемые результаты, с другой - отражение содержания образования. В центре целевых ориентиров - способности ребенка: проявлять инициативу и самостоятельность в разных видах деятельности; договариваться, учитывать интересы и чувства других; выражать свои мысли и желания; следовать социальным нормам поведения и правилам в разных видах деятельности; проявлять любознательность, задавать вопросы взрослым и сверстникам [2].

ФГОС ДО - это идеология дошкольного воспитания, основанная не на получении знаний и навыков, а на процессе позитивной социализации, личностного развития каждого ребенка, развития его инициативы и творческих способностей на основе сотрудничества со взрослыми и сверстниками. Федеральный государственный образовательный стандарт дошкольного образования требует от современных педагогов особого содержания и способов организации образовательной деятельности, особой образовательной практики.

1. Современную образовательную практику в ДОУ организует воспитатель, который должен иметь необходимое образование, кроме того, в целом соответствовать профессиональному стандарту «Педагог (педагогическая деятельность в сфере дошкольного, начального общего, основного общего, среднего общего образования) (воспитатель, учитель)» (далее Стандарт) [3]. Стандарт является системой обобщенных трудовых функций, каждая из которых включает общепедагогическую (обучение), воспитательную, развивающую, трудовая функция раскладывается на трудовые действия, умения и знания, необходимые для ее осуществления.

Многие десятилетия трудовой стаж, как опыт педагогической деятельности, был значим и для работодателей при устройстве на работу, и для аттестации воспитателей. Современный Стандарт не предъявляет требований к опыту и стажу практической деятельности воспитателя. Действительно, сегодня непонятно, опыт педагога - это достоинство или недостаток? Педагогам, имеющим многолетний опыт работы, бывает трудно перестроиться на новые требования образовательные практики, а молодым часто не хватает методических и психолого-педагогических знаний и умений.

В требованиях Стандарта одним из первых трудовых действий указывается участие педагога в разработке основной общеобразовательной программы в соответствии с ФГОС ДО. 
Стандарт предполагает, что воспитатель не только планирует и реализует образовательную работу в группе детей, но и является и активным составителем образовательной программы учреждения. Именно программа должна стать тем, чем педагог руководствуется при организации образовательной деятельности. Основная образовательная программа дошкольного образования - это нормативно-управленческий документ дошкольной образовательной организации, который разрабатывается, утверждается и реализуется на основе примерной образовательной программы [1].

В мае-сентябре 2019 г. нами было проведено анкетирование педагогов дошкольного образования (воспитателей, старших воспитателей), в том числе обучающихся в Томском государственном педагогическом университете (ТГПУ) по программам переподготовки, повышения квалификации и студентов заочного отделения по специальности «Логопедия». Всего было опрошено 189 человек. Цель анкетирования заключалась в выяснении уровня участия педагогов в создании образовательных программ, а также уровня владения содержанием ФГОС ДО. На один из вопросов: «Участвовали ли Вы в разработке и внесении изменений в Основную образовательную программу организации, в которой Вы работаете?» педагогам предлагалось выбрать варианты ответа: 1. Да, активно участвовал. 2. Да, был вынужден. 3. Нет, ничего не знал о такой возможности, но хочу участвовать. 4. Нет, это должны делать старшие воспитатели. По результатам опроса только 86 \% ответили, что это обязанность старших воспитателей; 8 \% респондентов принимали участие в разработке программы (ими оказались старшие воспитатели); 6 \% имеют желание участвовать в разработке программы, но не знают, как получить такую возможность.

Из полученных результатов очевиден вывод о том, что воспитатели не принимают участия в разработке Основной образовательной программы (ООП) и не считают это своей обязанностью. Разрабатывают программу старшие воспитатели (на основе типовых программ), а педагогам детского сада она предоставляется в готовом виде для реализации. Из содержания беседы с воспитателями выявлено, что отсутствие у них интереса к созданию программы обусловлено тем, что педагоги считают ФГОС ДО основным документом, а ООП - менее значимым. «Мы работаем по ФГОС» - самая частая фраза воспитателей. Фраза «Мы работаем в соответствии с Программой сада» не употребляется опрошенными нами педагогами дошкольных организаций. Можно предположить, что невовлеченность педагогов в разработку программ отрицательно повлияет на процесс их реализации, так как они являются для педагогов лишь внешней нормой, смысл которой им не совсем понятен.

Ранее, в 2016-2018 гг., нами было проведено анкетирование педагогов дошкольного образования (воспитателей, старших воспитателей), обучающихся в ТГПУ по программам переподготовки, повышения квалификации, и студентов заочного отделения специальности «Логопедия» с целью определения того, как они понимают смысл совместной образовательной деятельности. Всего в опросе приняли участие 215 педагогов из г. Томска, Томской области и других областей.

Участники следующим образом сформулировали определение «общение». Общение это: «делиться информацией, умение слушать и отвечать»; «речь, связь между людьми, для получения информации»; «умение слышать, слушать, давать обратную связь»; «сложный многоаспектный процесс, деловая или дружеская связь, обмен мнениями между людьми»; «делиться информацией, умение слушать и отвечать»; «обмен информацией, вербальным и невербальным путем»; «речь, связь между людьми для получения информации»; «обмен информацией, контактирование с другим человеком, группой»; «способ передачи, понимания, приятия информации между людьми, которое может быть вербальным и невербальным»; «контакт, понимание, взаимодействие, между людьми»; «взаимодействие педагога и детей 
друг с другом»; «взаимодействие людей, при котором участники общения передают информацию друг другу, эмоции, чувства, отношение друг к другу».

Как видно из приведенных ответов, педагоги понимают общение как обмен и принятие информации. Лишь 3 \% опрошенных соотносят общение со взаимодействием, под которым понимают обмен не только информацией, но и чувствами, эмоциями.

Взаимодействие в образовательной практике педагогов ДО понимается как совместная деятельность для решения задач или достижения цели: «совместная деятельность, сотрудничество»; «деятельность совместно с детьми, направленная»; «действие, которое направлено на общий результат»; «когда ни один из участвующих в какой-то деятельности не находится за пределами общения, но не вне общения, а напрямую включен в него»; «это действие нескольких лиц, структур и т. д., как правило, для одних и тех же задач»; «совместно с детьми выполняем определенные задачи с учетом интересов детей»; «форма сотрудничества для достижения поставленной цели».

Таким образом, различие в понимании общения и взаимодействия педагогами состоит в том, что общение организуется для обмена и передачи информации од одного участника к другому, а взаимодействие - это достижение общих целей через согласованные действия участников.

Одним из пунктов анкетирования являлось определение приоритетности результатов образовательной деятельности в ДО по пятибалльной шкале, где пять - это самое важное и далее по убыванию. На выбор были предложены: знания, умения, навыки; эмоциональное благополучие; игра; взаимодействие (с просьбой указать кого с кем); общение (с просьбой указать кого с кем). Получены следующие результаты анкетирования: эмоциональное благополучие ребенка - 26 \%; знания, умения, навыки - $21 \%$; общение - $19 \%$; взаимодействие $-18 \%$; игра $-15 \%$.

Результат опроса показал, что наиболее важным педагоги видят эмоциональное благополучие ребенка. Вторыми по значимости педагоги выбирают знания, умения, навыки, которые в ФГОС ДО не обозначены как основные ориентиры. Основной целью образования, согласно ФГОС ДО, становятся не знания, умения, навыки, а способности ребенка выражать свои мысли, принимать решения, доказывать правильность и обоснованность своего решения и принимать точку зрения других, проявлять любознательность, знать и учитывать социальные нормы поведения, способности выбирать себе род занятий, участников по совместной деятельности. Значимость игры, которой должна быть «пронизана» образовательная деятельность дошкольников и без которой детям дошкольникам не получить положительных эмоций, заняла «почетное» последнее место.

Из 215 опрошенных все отметили, что знают содержание Федерального государственного образовательного стандарта дошкольного образования, но только 35 \% изучали его самостоятельно, остальные узнали о его содержании, как и о Законе об образовании, из докладов конференций, семинаров или курсов повышения квалификации. Педагоги самостоятельно не вникают в содержание стандартов, программ или иных законодательных документов; педагоги ждут, когда к ним придут и точно скажут, как нужно работать в соответствии с ФГОС. Это соотносится с выводами анкетирования, проведенного в мае-сентябре 2019 г. относительно пассивности воспитателей ДОУ в создании образовательных программ.

Все примерные образовательные программы составляются в соответствии с ФГОС ДО, основная идея которого - идея развития. Методология развития как культурно-историческая методология понимания детства, идущая от Л. С. Выготского, Д. Б. Эльконина, А. В. Запорожца и В. В. Давыдова [4-8]. Кроме того, технология развития дошкольного детства есть технология особого развивающего взаимодействия между взрослыми и деть- 
ми, в которой ребенок вовсе не объект, а значимый участник образовательных отношений. Идеология развития исходит из признания самоценности детства: самоценность детства это не только подготовка к будущей жизни, а также и сама жизнь. В воспитании не могут применяться давление, принуждение и манипуляции, превращающие ребенка в послушную марионетку в руках воспитателя. Идеал развития - свободная, творческая и гармонически развитая личность, личность с равномерным развитием всех своих сторон [9]. Стандарт ФГОС ДО говорит о необходимости организовывать образовательную деятельность с учетом трех ведущих видов деятельностей детей дошкольного возраста: кроме игры необходимо реализовывать общение детей со взрослым и сверстниками; познавательно-исследовательскую деятельность.

Многие дошкольные образовательные организации г. Томска (МБДОУ № 65, МАДОУ № 57, МАДОУ № 94, МБДОУ № 89, МАДОУ № 96, МАДОУ № 28, МБДОУ № 133, МАДОУ № 61, МАДОУ № 60, МАДОУ № 100, МАДОУ № 6 и др.) реализуют Основную образовательную программу, составленную на основании примерной Комплексной образовательной программы дошкольного образования «Детство» (далее Программа), разработанной в соответствии с ФГОС ДО [10]. Программа является результатом научной и практической деятельности коллектива преподавателей кафедры дошкольной педагогики Российского государственного педагогического университета им. А. И. Герцена - Т. И. Бабаевой, А. Г. Гогоберидзе, О. В. Солнцевой и др. Особенностью программы является определение содержания и организации образовательной деятельности детей от рождения и до семи (восьми) лет. Основной единицей образовательного процесса по данной Программе выступает образовательная ситуация, т. е. такая форма совместной деятельности педагога и детей, которая планируется и целенаправленно организуется педагогом с целью решения определенных задач развития, воспитания и обучения $[10,11]$. Главными задачами совместной деятельности педагога и детей являются формирование у детей новых умений в разных видах деятельности и представлений; развитие способности рассуждать и делать выводы.

В Программе указано, что воспитатель создает разнообразные образовательные ситуации, побуждающие детей применять свои знания и умения, активно искать новые пути решения возникшей в ситуации задачи, проявлять эмоциональную отзывчивость и творчество. Кроме того, организованные воспитателем образовательные ситуации должны ставить детей перед необходимостью понять, принять и разрешить поставленную задачу [10].

Совместная деятельность педагога и детей должна быть организована так, чтобы дети в процессе взаимодействия играли и экспериментировали. При этом взаимодействии приобретаются знания, формируются умения и навыки. Совместная образовательная деятельность педагога и детей является содержанием образования, от качества ее организации зависит весь образовательный процесс. В Программе разъясняется, что если ранее совместная деятельность детей и взрослого осуществлялась вне образовательной деятельности и воспринималась как дополнение к образовательной, то теперь это основная линия работы педагога [10].

В концепции педагогики совместной деятельности (Г. Н. Прозументова $[12,13])$ образовательная практика представлена как практика соорганизации взрослых и детей, их взаимодействия и взаимоотношений. Организация совместной деятельности представлена в трех моделях: авторитарной, лидерской, партнерской. Современный педагог должен владеть всеми моделями и постепенно двигаться от тотального авторитаризма к лидерству и партнерству.

Педагогу, имеющему многолетний опыт применения авторитарной модели, трудно создать ситуацию, где ребенок может высказаться, задать вопрос, сделать выбор. Если адми- 
нистративно запретить воспитателям использовать привычные понятия «структура», «зонирование», «занятие» и заменить их не всегда понятными педагогам определениями «непрерывная образовательная деятельность» и «непосредственная образовательная деятельность», то педагоги попадут в ситуацию напряжения. Воспитатели не понимают, как отказаться от того, чему учили в университетах, учили педагоги-наставники, от того, что ты много лет использовал в педагогической практике.

Запретить - просто, гораздо сложнее соорганизовать новое и старое (формы, содержание, методы, приемы работы). Часть образовательного процесса должна оставаться в логике закрытого совместного действия. Показ, четкое объяснение, инструкция по выполнению должны присутствовать. Без этого нельзя. Только тогда, когда ребенок знает, умеет, владеет, он может рассуждать, творить, доказывать свою точку зрения. Но авторитарная модель не должна быть тотальной: педагогическое мастерство состоит в соорганизации использования всех трех моделей совместной деятельности, где открытость приоритетна и является «высшим пилотажем» в организации образовательной деятельности, путь к которой возможен только благодаря переходам от одной модели к другой.

По нашим наблюдениям, воспитатели, оказавшись в ситуации тотального авторитаризма, когда на них оказывают давление с целью заставить забыть весь прежний опыт и начать все с чистого листа, проявляют агрессию, раздражение. Педагоги вынуждены либо уходить из профессии, либо приспосабливаться к новым требованиям. Переход от авторитарной модели формализуется: внешние формы изменили, работу детей в подгруппах организовали, а при детальном рассмотрении обнаруживается, что педагогический процесс иллюзорно демонстрирует партнерское взаимодействие участников образовательной деятельности.

С целью понимания особенностей практической реализации образовательной программы «Детство» в сентябре 2019 г. мы посетили образовательные ситуации в старших и подготовительных группах МБДОУ № 133 г. Томска. Формы организации образовательной деятельности в данном учреждении весьма разнообразны: в проведении занятий используются круг и полукруг, большое внимание уделяется работам в так называемых центрах, активно используют зону ковра, игровые зоны. В «центрах» дети организуются в малые группы по 3-4 человека, во всех «центрах» организован один вид деятельности, например аппликация, но разные техники аппликаций, разные материалы, различные сюжеты.

Примеры образовательных ситуаций с детьми старшего дошкольного возраста:

Ситуащия 1. Педагог раздает детям жетоны с нумерацией 1, 2, 3, 4. Детям предлагает сесть за столы в «центр» согласно цифрам. Если у ребенка цифра 1, то за стол с цифрой 1, если 2, то за тот, который обозначен цифрой 2, и т. д. По мнению педагога, детям был предложен выбор деятельности, в каком «центре» работать. Формально - да. Но по факту ребенок не делал выбор. Он действовал по безвариативной инструкции педагога: какую цифру воспитатель дал, соответственно, в тот «центр» он и пошел. Ребенок выполнил то, что решил за него взрослый.

Cитуащия 2. Дети встречаются с гостем, лесным ежиком, который дарит кленовые и дубовые листья. Каждому ребенку - по одному листочку. Воспитатель предлагает детям: «Пройдите и сядьте в „центры“ за столы. За один стол, обозначенный листом кленового дерева, сядьте дети, которым ежик подарил кленовый листочек. За второй стол, обозначенный листком дубового дерева, сядьте дети, которым ежик подарил дубовый листочек. Все нашли свои столы? Молодцы! Я соберу листочки, чтобы они вам не мешали, вы их заберете после занятия. Сейчас посмотрите на столы. У вас у каждого есть инструкция выполнения. За первый столом мы рисуем ежика. За вторым - лепим ежика». Используемый прием с гостем и листочками дал возможность разделить детей на две группы. И ежик, и листоч- 
ки - средства выполнения этой задачи. Ежик молча принес, раздал и покинул участников ситуации. Листья не сравнивались, не угадывалось, от какого они дерева, не анализировались по форме, размеру, цвету. Детям их раздали, назвали и дали четкую инструкцию: сесть согласно листьям за столы и вернуть листья воспитателю. Выбор деятельности - лепить или рисовать - ребенок не делал. В процессе работы каждый ребенок выполнял задание по четкой инструкции (лист бумаги, где схематично изображена последовательность выполнения). У каждого ребенка своя инструкция, но она одинаковая с теми, кто занимался лепкой. У тех, кто рисовал, другая, но опыт у всех одинаковый. Выполнение не предполагало обсуждения и взаимодействия. По мнению педагога, деятельность совместна - дети выполняют задания в малых группах за одним столом, в одном «центре»; деятельность вариативна дети в разных «центрах» вовлечены в разную продуктивную деятельность.

Использование «центров» в педагогической практике показывает, что воспитатели знают о необходимости иных форм организации, отличных от классно-урочных форм. Педагоги используют формы, где возможно объединение детей в общий круг, полукруг, малые группы за одним столом.

Анализ педагогических ситуаций позволил сделать вывод, что совместно дети работают в «центрах», в малых группах - формально. В действительности дети только сидят вместе, выполняя каждый свое задание. Нет обсуждения выполняемой работы для принятия решения. Задание безвариативно. Задача каждого ребенка - правильно сделать свою работу, работу, на которую ребенок не влияет и она независима от других. Правильно можно сделать только при условии точного соблюдения инструкции. Нет места детской инициативе, все задано «сверху» воспитателем.

Для детей нет возможности проявлять инициативу и самостоятельность в разных видах деятельности - игре, общении, конструировании и др. Дети не могут выбирать себе род занятий, партнеров по совместной деятельности. Воспитатели словно боятся доверить детям выбор, дать возможность высказаться, предложить варианты. Тогда как согласно методическому содержанию Программы «Детство», воспитатель создает разнообразные образовательные ситуации, побуждающие детей применять свои знания и умения, активно искать новые пути решения возникшей в ситуации задачи. Организованные воспитателем образовательные ситуации ставят детей перед необходимостью понять, принять и разрешить поставленную задачу [10].

Совместная деятельность совместна только тем, что все участники находятся в одном помещении. Участники такой совместной деятельности не могут влиять на деятельность или изменять ее. У ребенка нет возможности обратиться ко всем, только ответить взрослому. Педагог ограничивает детей в пространстве, не учитывает мнения детей, не предоставляет возможности высказать свое мнение, диктует решения задания, выбор способа работы, определяет партнера деятельности, не допускает незапланированных отступлений от плана образовательной деятельности [14-16]. Модель организации совместной деятельности авторитарная: педагог является только руководителем, а ребенок исполнителем [17-20].

Данная ситуация типична для данной образовательной организации. Выбор форм, методов, средств, содержания организации образовательной ситуации зависит от того, в каком коллективе педагог находится. Решение задач, которые поставлены сегодня перед образованием, осуществляется не одним отдельно взятым педагогом, а всем педагогическим коллективом. Методическое руководство педагогическим коллективом дошкольной образовательной организации определяет качественную реализацию образовательной деятельности педагогов в работе с детьми. Покажем на примере, как организуется такое руководство и что думают про него воспитатели. 
Пример 1. Методическое руководство организации образовательной деятельности педагогов в дошкольном учреждении «А» г. Томска.

Сентябрь 2019 года. Фрагмент беседы со старшим воспитателем детского сада «А»: «Педагогам необходимо разъяснять работу по ФГОС ДО. Прежде всего, нужно менять образовательную среду группы. Игры расположены не по Центрам, а математический материал на одной полке с материалом по развитию речи. Такого быть не должно. Должны быть Центры, согласно пяти образовательным областям ФГОС ДО. Если будут Центры, дети будут иметь выбор деятельности. Иначе развития ребенка не произойдет, а согласно ФГОС ДО мы должны создавать условия для развития ребенка. Педагог должен понимать, что важно дать ребенку выбор, не учить, а развивать ребенка в образовательных областях: социально-коммуникативное развитие, познавательное, речевое, художественно-эстетическое, физическое развитие. Не хотят наши педагоги этого понимать, для них все по старинке: как работали, так и работают. Не понимают, что знания, умения, навыки - это то, о чем должны забыть. Они развитием детей должны заниматься».

Сентябрь 2019 года. Фрагмент беседы с воспитателем детского сада «А»: «Я спорить не буду. Сказали такие сделать центры - сделаю. Сказали коробки поменять - поменяю коробки. Если для ФГОС надо - поставим как надо. Сегодня говорят для ФГОС одно надо, завтра - противоположное. Спрашивать „зачем?“; „почему?“ - я не буду, толком не ответят, а виновата останусь я. Мне главное понять, что точно нужно сделать. Столько лет работаем по этому ФГОС, все не научимся. Раньше придумывала, как лучше, что организовать, что, как удобнее поставить... А сейчас... Надо выбор - дадим выбор, надо центры пусть будут центры».

Как видно из приведенного примера, в данном учреждении старший воспитатель дает указания и требует его выполнения без разъяснения, объяснения, обсуждения с коллективом. Семинар, проведенный на тему «Образовательная среда в соответствии с ФГОС ДО», был организован в форме монолога руководителя, в виде точных цитат основной образовательной программы «Детство». Возможности обсудить содержание, задать вопросы педагогам не предоставили. Открыто указывается на необходимость забыть все «старое», прекратить использовать привычное зонирование, использовать только «центры», никакой инициативы.

Требование организовывать только развитие детей противоречит Программе, где кроме развития, в обязанности педагога входит воспитание и обучение, а одной из главных задач совместной деятельности педагога и детей является формирование у детей новых умений в разных видах деятельности. Воспитатели не могут понять это противоречие. Беседа со старшим воспитателем, педагогами, посещение семинара позволили сделать вывод не просто об авторитаризме руководства, но и об отсутствии культуры авторитаризма. Когда указания к выполнению даются, но зачем это надо, почему именно так, не поясняется. Старший методист затрудняется не только с организацией деятельности воспитателей, но и сам имеет методические затруднения и дефициты.

Иной пример организации совместной образовательной ситуации мы наблюдали в подготовительной группе МАДОУ № 6 г. Томска, реализующего программу «Детство». Образовательная ситуация организована в форме сказочного путешествия. Одним из этапов путешествия было задание по преодолению препятствия, выполнение которого дает возможность продолжить путешествие. Детям необходимо приготовить различные волшебные супы. По сюжету путешествия их должно быть пять. Чтобы быстро приготовить разные супы, дети делятся на пять команд по четыре человека. В команды дети группируются самостоятельно, выбирая партнеров по совместной деятельности. У каждой команды есть стол для приготовления, на котором пронумерованные конверты: 1, 2, 3. Открыв первый 
конверт, команда попадает в ситуацию совместного выбора: детям необходимо выбрать из предложенных способов приготовления пищи, изображенных на предметных картинках: в русской, кирпичной печи; на электрической плите; костре; в микроволновой печи; электрическом духовом шкафу. В процессе выбора дети обсуждают, высказывают свое желание, убеждают, слушают мнения других участников группы, принимают общее решение.

Во втором конверте детям предложены картинки: кастрюли (металлические, стеклянные); железные, подвесные котелки; печные, железные чугуны; стеклянные кастрюли. Многообразие вариантов (форма, размер, цвет) необходимо для выбора детьми посуды соответственно способу приготовления и желанию детей. Следуя содержанию третьего конверта, дети выбирают, какой суп они приготовят (уху, борщ, рассольник, щи, овощной, сырный и др.) продукты, составляющие содержание супа: мясо, рыбу, курицу, лук, различные овощи и приправы.

После «приготовления» супа дети выбирают одного из группы для представления готового блюда. В процессе выбора дети предлагают свои кандидатуры или участников своей группы. Обсуждают, голосуют или договариваются выбрать делегата путем считалочки. Пять готовых блюд представляются докладчиками. После представления дети задают вопросы докладчику: «Почему выбрали такую посуду для приготовления?», «На костре уху готовят, а вы почему борщ?». Могут высказать свое мнение: «Уха со свеклой не варится, это невкусно», «Для кирпичной печи котелок нужен, стеклянная разломается».

В данной образовательной ситуации педагог создает детям возможность высказывать свое мнение, задавать вопросы, свободно перемещаться в пространстве. Уважительно принимает неожиданные отступления детей от плана образовательной деятельности. Создает ситуации выбора в преодолении затруднений: эмоциональных, интеллектуальных, коммуникативных (способа работы, партнера деятельности и т. п.). Дети анализируют, предлагают варианты заданий, решений, обсуждают, рассматривают варианты решений, пробуют и т. П. Педагог в данном образовательном процессе - организатор-участник, ребенок - значимый и влиятельный участник образовательной деятельности.

Пример 2. Методическое руководство организации образовательной деятельности педагогов в МАДОУ № 61, г. Томска.

Сентябрь 2019 года. Фрагмент беседы со стариим воспитателем МАДОУ № 61 Светланой Витальевной: «Нашим педагогам очень полезно собраться, обсудить. Хотя конечно, все разные. Есть те, кто с душой вкладывается, продумывает до мелочей, есть те, кто формально организует. У нас много открытых мероприятий: для родителей, для учителей начальных классов. Им подготовительные группы традиционно готовят мероприятие. Для воспитателей, с целью обмена опыта, обязательно. После проведения всегда обсуждаем, хвалим обязательно. Педагоги - народ ранимый. Но ничего, пожелания тоже нужны. Обсуждаем где, как, что можно было иначе организовать. Ведь нет предела совершенства. У каждого свой взгляд, свой опыт, пусть выскажутся. Иногда молодые педагоги очень дельные предложения выдают».

Октябрь 2019 года. Семинар на тему «Планирование образовательной деятельности: проблемь;; перспективы». Фрагмент диалога стармего воспитателя МАДОУ № 61 и педагогов детского сада.

Стариий воспитатель Светлана Витальевна: «Вчера была в младшей группе. Дети, беседуя со мной, похвастались игрушками: слоном и комаром. Не помню, почему и как, но возник вопрос: „Что общего между комаром и слоном?“. Дети так активно это обсуждали, столько вариантов предложили, от реальных: „И у слона, и у комара хобот есть. Слон воду пьет, а комар кровь. Они без хобота умрут“. До фантастичных: „У комара крылья, он на 
крыльях летает, а у слона крылья-уши, он ушами машет и летает. Ему так можно бананы срывать и кушать. Или сразу сосать, как комар кровь“. Взяв эти игрушки в среднюю группу, в беседе с детьми показала игрушки и предложила найти сходство. Я заметила, что дети менее активны в ответах. Ответы краткие, без рассуждений. Часть детей не принимает участия в беседе, отмалчивается. Меня это насторожило. Эксперимент в старшей и подготовительной группах показал, что дети затрудняются в ответах, внимательно слушают, но рассуждать, обсуждать, а тем более спорить и не пытаются. Мне показалось, что они пытаются угадать верный ответ. А его ведь здесь просто нет. Старшие дошкольники робеют от отсутствия рамок в ответах. Коллеги, мы что-то делаем не так. Почему инициатива детей снижается с возрастом? Почему они становятся осторожны в суждениях?».

Воспитатель старшей группь $O$. . Н.: «Ну, мои ведь дети говорили, называли. Они ведь правильно говорили?»

Светлана Витальевна: «Да. Здесь речь не о правильности, а о качестве ответа. Пока сама не поняла, но что-то меняется с возрастом. И это что-то неестественно. Наоборот, старшие дети должны быть более разговорчивы. У них ведь словарный запас богаче, и знания, как и опыт общения со взрослыми».

Bоспитатель старшей группы O. Н.: «Может это то, о чем мы в прошлый раз, когда конспекты обсуждали? Ну, что ответы детей на вопросы воспитателей, в основном, однозначны. Да, нет. Хотим, не хотим. Мало вопросов с разными вариантами правильных ответов».

Светлана Витальевна: «Да, коллеги. Я тоже об этом подумала. Действительно. Видимо, недостаточно мы этому внимание уделяем, больше надо. Нужно продумывать, как их разговорить. Как создать ситуации с возможностью детям высказаться. Давайте к следующему семинару предложим варианты. Ведь у многих уже есть такой опыт. Поделимся опытом, идеями, обсудим».

Старший воспитатель данного учреждения сам является педагогом-исследователем. Несмотря на занимаемую должность, считает необходимым самому организовывать педагогические ситуации с детьми, наблюдать, делать выводы, обсуждать результаты с педагогами. Занятия посещает не с первостепенной целью контроля, хотя и это входит в его обязанности, но прежде всего с целью наставничества, методического сопровождения и направления.

Наблюдая за работой педагогов двух разных детских садов, мы увидели разное методическое руководство педагогами, реализующими одну и ту же образовательную программу. Анализ анкетирования педагогов, сравнительный анализ образовательных и управленческих ситуаций в двух разных учреждениях позволяет сделать выводы:

1. Воспитатели не проявляют активности при составлении ООП детского сада и не считают ее документом, который конкретизирует содержание, формы, методы их педагогической деятельности. Не участвуя в составлении ООП, педагоги лишают себя возможности обсуждать, выбирать, знать и понимать содержание данной программы самостоятельно. Выстраивать образовательный процесс осознанно, а не ждать, когда старшие воспитатели скажут, как правильно работать.

2. Педагоги не осознают ценности совместной деятельности. Оказавшись в ситуации, вынуждающей отойти от авторитарной модели, испытывают трудности и дефициты понимания нового содержания своей работы с детьми. Современная образовательная практика нуждается в соорганизации моделей совместной деятельности: нет необходимости отказываться от авторитарной модели, она важна и необходима, но только как часть образовательной деятельности. Важно движение воспитателя от одной модели к другой: благодаря таким переходам открытость совместного действия взрослого и ребенка становится приоритетной при условии дополнительности разных моделей взаимодействия. 
3. Методическое сопровождение педагогов со стороны старших воспитателей оказывает большое влияние на умение педагога организовывать образовательные ситуации обращенного и открытого совместного действия с детьми. При тотальном авторитаризме и отсутствии качественной методической поддержки воспитатели формализуют открытость взаимодействия: дети остаются пассивными, выполняют действия, спланированные педагогом. Тогда как полноценное развитие ребенка нуждается в познавательной активности, проявляющейся в различных пробах, экспериментах, предполагающих выбор для получения результата.

Трудности организации совместной образовательной деятельности в условиях дошкольного образования вызывают ряд вопросов, ответы на которые могут быть найдены в процессе дальнейшего исследования.

\section{Список литературы}

1. Федеральный закон об образовании с комментариями специалистов. Дошкольная образовательная организация в контексте развития системы образования / Л. А. Львова [и др.]; под ред. Л. А. Львова. М.: АРКТИ, 2015. 112 с.

2. Федеральный государственный образовательный стандарт дошкольного образования. М.: Перспектива, 2014. 32 c.

3. Приказ Министерства труда и социальной защиты Российской Федерации «Об утверждении профессионального стандарта „Педагог (педагогическая деятельность в сфере дошкольного, начального общего, основного общего, среднего общего образования) (воспитатель, учитель)“ от 18 октября 2013 г. № 544н». URL: https://rosmintrud.ru/docs/mintrud/orders/129 (дата обращения: 23.01.2019).

4. Выготский Л. С. Педагогическая психология. М.: АСТ, 2005. 670 с.

5. Зинченко В. П., Пружинин Б. И., Щедрина Т. Г. Истоки культурно-исторической психологии: философскогуманитарный контекст. М.: РОССПЭН, 2010. 415 с.

6. Кулагин И. Ю., Колюцкий В. Н. Возрастная психология. Полный жизненный цикл развития человека: развитие человека от рождения до поздней зрелости: учеб. пособие для вузов. М.: Академический проект, 2018.420 c.

7. Микляева Н. В., Микляева Ю. В., Виноградова Н. А. Дошкольная педагогика: учеб. для академического бакалавриата / под общ. ред. Н. В. Микляевой. 2-е изд., перераб. и доп. М.: Юрайт, 2019. 411 с.

8. Педагогика: теории, системы, технологии: учеб. для вузов / И. Б. Котова [и др.].; под ред. С. А. Смирнова. 8-е изд., стереотип. М.: Академия, 2008. 512 с.

9. Шацкий С. Т., Шацкая В. Н. Сохраним то, что есть в детях. М.: Карапуз, 2011. 346 с.

10. Комплексная образовательная программа дошкольного образования «Детство» / Т. И. Бабаева, А. Г. Гогоберидзе, О. В. Солнцева и др. СПб.: Детство-Пресс, 2019. 352 с.

11. Федеральный институт развития образования. Навигатор образовательных программ дошкольного образования. URL: https:/firo.ranepa.ru/obrazovanie/fgos/184-obrazovatelniye-programmi-oshkolnogo-obrazovaniya (дата обращения: 23.01.2019).

12. Прозументова Г. Н. Педагогика совместной деятельности: смысловые контексты и образовательная реальность // Школа совместной деятельности: разработка образовательных программ в развивающейся школе / под ред. Г. Н. Прозументовой. Томск: Дельтаплан, 2002. С. 4-16.

13. Поздеева С. И. Типология уроков в концепции педагогики совместной деятельности // Научно-педагогическое обозрение (Pedagogical Review). 2016. Вып. 3 (13). С. 36-41.

14. Поздеева С. И. Инновационное развитие современной начальной школы: построение открытого совместного действия педагога и ребенка. Томск: Изд-во ТГПУ, 2013. 168 с.

15. Поздеева С. И. Начальная школа - пространство совместной деятельности // Вестн. Томского гос. пед. унта (TSPU Bulletin). 2003. Вып. 2 (34). С. 58-67.

16. Поздеева С. И. Образовательное содержание совместной деятельности в начальной школе. Томск: Дельтаплан, 2004. $311 \mathrm{c.}$

17. Поздеева С. И., Токарева Т. А. Организационно-методическое обеспечение совместной образовательной деятельности педагога и ребенка // Детский сад: теория и практика. 2011. № 7. С. 54-60.

18. Поздеева С. И. Открытое совместное действие педагога и ребенка: содержание, признаки, результаты // Вестн. Томского гос. пед. ун-та (TSPU Bulletin). 2012. Вып. 4 (119). С. 198-202. 
19. Образовательное содержание совместной деятельности взрослых и детей в школе: управление и становление / под ред. Г. Н. Прозументовой, С. И. Поздеевой. Томск: Изд-во Том. ЦНТИ, 2015. Кн. 7. 288 с.

20. Токарева Т. А. Изменения содержание образовательной деятельности в условиях нового федерального государственного стандарта // Научно-педагогическое обозрение (Pedagogical Review). 2016. Вып. 2 (12). C. 118-123.

Токарева Татьяна Алексеевна, старший преподаватель, Томский государственный педагогический университет (ул. Киевская, 60, Томск, Россия, 634061). E-mail: abatina74@mail.ru

Материал поступил в редакциию 03.02.2020.

DOI 10.23951/2307-6127-2020-2-79-91

\section{MODERN REQUIREMENTS FOR THE ORGANIZATION OF THE JOINT EDUCATIONAL ACTIVITIES IN THE CONTEXT OF THE PRESCHOOL EDUCATION: NECESSITY AND REALITY}

\section{T. A. Tokareva}

\section{Tomsk State Pedagogical University, Tomsk, Russian Federation}

The article raises the problem of the readiness of teachers of preschool educational organizations to work on the new Federal State Educational Standard, which pays great attention to the organization of the joint educational activities of a teacher with children. The results of two questionnaire surveys of kindergarten teachers are given, in the course of which it was found out, firstly, the level of the involvement of teachers in the development of educational programs, secondly, their understanding of the results of preschool education, and thirdly, the identification of priority areas for the development of a preschool child. It was found that the majority of teachers take an executive position in relation to educational programs, they are focused not on the personal development of children, but on the formation of their knowledge, skills, teachers underestimate the value of the game and research activities for children's development. Real educational situations of the organization of the teacher's joint activities with children are described, illustrating that teachers do not always understand how to make a child an active participant in interacting with an adult and how to get away from the total use of the authoritarian model of joint activity towards leadership and partnership. It is concluded that there is a relationship between the level of the methodological support in the kindergarten, including the position of the senior educator, and the ability of the teacher to organize educational situations of reversed and open joint action with children.

Keywords: educational program, joint educational activity, open joint action, educational situation, preschool education.

\section{References}

1. Federal'nyy zakon ob obrazovanii s kommentariyami spetsialistov. Doshkol'naya obrazovatel'naya organizatsiya $v$ kontekste razvitiya sistemy obrazovaniya [Federal law on education with comments from specialists. Preschool educational organization in the context of the development of the education system]. Moscow, ARKTI Publ., 2015. 112 p. (in Russian).

2. Federal'nyy gosudarstvennyy obrazovatel'nyy standart doshkol'nogo obrazovaniya [Federal state educational standard for preschool education]. Moscow, Perspektiva Publ., 2014. 32 p. (in Russian).

3. Prikaz Ministerstva truda i sotsial'noy zashchity Rossiyskoy Federatsii «Ob utverzhdenii professional'nogo standarta "Pedagog (pedagogicheskaya deyatel'nost'v sfere doshkol'nogo, nachal'nogo obshchego, osnovnogo obshchego, srednego obshchego obrazovaniya) (vospitatel', uchitel')” ot 18 oktyabrya 2013 g. № $544 n$ [Order of the Ministry of labor and social protection of the Russian Federation "On approval of the professional standard «Teacher (pedagogical activity in the field of preschool, primary General, basic General, secondary General education) (educator, teacher)" dated 18 October 2013 No. 544n] (in Russian). URL: https://rosmintrud.ru/docs/mintrud/ orders/129 (accessed 23 January 2019). 
4. Vygotsky L. S. Pedagogicheskaya psikhologiya [Pedagogical psychology]. Moscow, AST Publ., 2005. 670 p. (in Russian).

5. Zinchenko V. P., Pruzhinin B. I., Shchedrina T. G. Istoki kul turno-istoricheskoy psikhologii: filosofsko-gumanitarnyy kontekst [The Origins of cultural and historical psychology: a philosophical and humanitarian context]. Moscow, ROSSPEN Publ., 2010. 415 p. (in Russian).

6. Kulagin I. Yu. Vozrastnaya psikhologiya. Polnyy zhiznennyy tsikl razvitiya cheloveka: razvitiye cheloveka ot rozhdeniya do pozdney zrelosti: uchebnoye posobiye dlya vuzov [Age-related psychology. The full life cycle of human development: human development from birth to late adulthood: a textbook for universities]. Moscow, Akademicheskiy proyekt Publ., 2018. 420 p. (in Russian).

7. Miklyayeva N. V., Miklyayeva Yu. V., Vinogradova N. A. Doshkol'naya pedagogika: uchebnik dlya akademicheskogo bakalavriata. Pod obshchey red. N. V. Miklyayevoy [Preschool pedagogy: textbook for academic baccalaureate. Edited by N. V. Miklyayeva]. Moscow, Yurayt Publ., 2019. 411 p. (in Russian).

8. Kotova I. B. et al. Pedagogika: teoriya, sistema, tekhnologii: uchebnik dlya vuzov. Pod red. S. A. Smirnova [Pedagogy: theories, systems, technologies: textbook for universities. Ed. S. A. Smirnov]. Moscow, Akademiya Publ., 2008. 512 p. (in Russian).

9. Shatsky S. T., Shatskaya V. N. Sokhranim to, chto yest'v detyakh [Save what is in children]. Moscow, Karapuz Publ., 2011. 346 p. (in Russian).

10. Babayeva T. I., Gogoberidze A. G., Solntseva O. V. Kompleksnaya obrazovatel'naya programma doshkol'nogo obrazovaniya "Detstvo" [Complex educational program of preschool education "Detstvo"]. Saint Petersburg, Detstvo-Press Publ., 2019. 352 p. (in Russian).

11. Federal'nyy institut razvitiya obrazovaniya. Navigator obrazovatel'nykh programm doshkol'nogo obrazovaniya [Federal Institute for education development. Navigator of educational programs of preschool education] (in Russian). URL: https://firo.ranepa.ru/obrazovanie/fgos/184-obrazovatelniye-programmi-oshkolnogo-obrazovaniya (accessed 23 January 2019).

12. Prozumentova G. N. Pedagogika sovmestnoy deyatel'nosti: smyslovye konteksty i obrazovatelnaya real'nost' [Pedagogics of a joint activity: semantic contexts and educational reality]. Shkola sovmestnoy deyatel'nosti: razrabotka obrazovatelnykh programm v razvivayushcheysya shkole [School of the joint activity: the development of educational programs at the developing school]. Tomsk, Del'taplan Publ., 2002. Pp. 4-16 (in Russian).

13. Pozdeyeva S. I. Tipologiya urokov v kontseptsii pedagogiki sovmestnoy deyatel'nosti [Typology of lessons in the concept of pedagogy of joint activity]. Nauchno-pedagogicheskoye obozreniye-Pedagogical Review, 2016, vol. 3 (13), pp. 36-41 (in Russian).

14. Pozdeyeva S. I. Innovatsionnoye razvitiye sovremennoy nachal'noy shkoly: postroyeniye otkrytogo sovmestnogo deystviya pedagoga i rebenka [Innovative development of modern primary school: building an open joint action of the teacher and the child]. Tomsk, TSPU Publ., 2013. 168 p. (in Russian).

15. Pozdeyeva S. I. Nachal'naya shkola - prostranstvo sovmestnoy deyatel'nosti [Elementary school space of joint activity]. Vestnik Tomskogo gosudarstvennogo pedagogicheskogo universiteta - TSPU Bulletin, 2003, vol. 2 (34), pp. 58-67 (in Russian).

16. Pozdeyeva S. I. Obrazovatel'noye soderzhaniye sovmestnoy deyatel'nosti v nachal'noy shkole [The Educational content of the joint activity in a primary school]. Tomsk, Del'taplan Publ., 2004. 311 p. (in Russian).

17. Pozdeyeva S. I., Tokareva T. A. Organizatsionno-metodicheskoye obespecheniye sovmestnoy obrazovatel'noy deyatel'nosti pedagoga i rebenka [Organizational and methodological support for joint educational activities of a teacher and a child]. Detskiy sad: teoriya i praktika, 2011, no. 7, pp. 54-60 (in Russian).

18. Pozdeyeva S. I. Otkrytoye sovmestnoye deystviye pedagoga i rebyonka: soderzhaniye, priznaki, rezul'taty [Open joint programme of teacher and a child: content, evidence, results]. Vestnik Tomskogo gosudarstvennogo pedagogicheskogo universiteta - TSPU Bulletin, 2012, vol. 4 (119), pp. 198-202 (in Russian).

19. Obrazovatel'noye soderzhaniye sovmestnoy deyatel'nosti vzroslykh i detey v shkole: upravleniye i stanovleniye. Kn. 7. Pod red. G. N. Prozumentovoy, S. I. Pozdeyevoy [Educational content of the joint activity of adults and children in the school: management and formation. Book 7. Ed. by G. N. Prozumentova, S. I. Pozdeyeva]. Tomsk, Tomsk TsNTI Publ., 2015. 288 p. (in Russian).

20. Tokareva T. A. Izmeneniya soderzhaniya obrazovatel'noy deyatel'nosti v usloviyakh novogo federal'nogo gosudarstvennogo standarta [Changes in the content of educational activities under the new Federal state standard]. Nauchno-pedagogicheskoye obozreniye - Pedagogical Review, 2016, vol. 2 (12), pp. 118-123 (in Russian).

Tokareva T. A., Tomsk State Pedagogical University (ul. Kiyevskaya, 60, Tomsk, Russian Federation, 634061). E-mail: abatina74@mail.ru 